\title{
Analysis of nutritional elements in Indian medicinal herbs used to cure general weakness
}

\author{
Arun Kumar ${ }^{1^{*}}$, Ram Prakash Singh ${ }^{1}$, Narendra Pal Singh ${ }^{2}$ \\ ${ }^{1}$ Department of Chemistry, Hindu P.G. College, Varanasi, India; ${ }^{*}$ Corresponding Author: arun.150476@gmail.com \\ ${ }^{2}$ Institute of Pharmacy, V.B.S. Purvanchal University, Jaunpur, India
}

Received 14 January 2012; revised 18 February 2012; accepted 29 February 2012

\begin{abstract}
Concept of trace elements being "the Inorganic Switches" has evolved during last several decades. Ayurveda, the traditional Indian medicinal system also emphasises the importance of $\mathrm{mi}$ nor and trace elements in human health and disease. To evaluate elemental contents of some commonly used to cure general weakness, 3 medicine herbs namely Beezband (seeds), Gokshur (fruit) and Talmakhana (seeds) have been analyzed for four minor ( $\mathrm{Na}, \mathrm{K}, \mathrm{Mg}$ and $\mathrm{Ca}$ ) and eight trace elements $(\mathrm{Cr}, \mathrm{Mn}, \mathrm{Fe}, \mathrm{Co}, \mathrm{Ni}, \mathrm{Cu}, \mathrm{Zn}$ and $\mathrm{Cd}$ ) by atomic absorption spectrometry and flame photometry. Their accuracy was measured by replicate analyses. In general, elemental contents were found in varying amounts with large range. It is observed that many of medicinal herbs are enriched in one or more elements. Since these elements are bioavailable in natural form, probably in combination with organic constituents, these are likely to be easily assimilated by human Bodies. Besides them, two toxic elements $\mathrm{Ni}$ and $\mathrm{Cd}$ were also found in insignificant amounts as these are likely to have originated from environmental contamination.
\end{abstract}

Keywords: Nutritional Elements; Herbs for General Problem

\section{INTRODUCTION}

There are ample evidences of herbs being used in the treatment of diseases and for revitalising body system in almost all ancient civilizations [1-5]. Plants were the mainstay of many medicines having mystical and almost super natural healing power. There are many references to the curative properties of several herbs in the ancient Indian literature, Rigveda, though a more detailed amount is found in the Atharvaveda from where Ayurveda, the Indian traditional health care system (ayus = life, veda $=$ knowledge, meaning science of life) originated. Fairly compreshensive information about herbs has been recorded [6,7] in two treatises Charak Samhita and Shusruta Samhita - a base for Ayurvedic system of medicine. Looking to the importance of herbs, A Compendium of Indian Medicinal Plants in six volumes has been published [8]. Herbs play a significant role in modern times, when the damaging effects of food processing and over medication have assumed alarming proportions. These are now being increasingly used in cosmetics, foods as well as alternative medicine [9]. Besides lipids, proteins and carbohydrates required for human growth, supply of optimum quantities of inorganic micronutrients is also essential $[10,11]$. Several micronutrients such as $\mathrm{Cr}, \mathrm{Mn}, \mathrm{Fe}, \mathrm{Cu}$ and $\mathrm{Zn}$ etc., constitute a small fraction of our diet and play an important role in metabolic processes. Their excess or deficiency may disturb normal biochemical functions of the body [12]. Two main criteria considered for essentiality of elements are: first, its absence from diet results in departure from normal growth and metabolism; and second, the replacement of an element may suppress pathological symptoms.

The composition of biological systems is so complex that the trace elements are totally masked by major constituents, and hence difficult to determine [13]. Some techniques, widely used in trace element analysis [14] are atomic absorption spectrophotometry (AAS), energy dispersive X-ray fluorescence [15] (EDXRF), electro thermal atomic absorption spectrometry [16] (ETAAS), inductively coupled plasma-atomic emission spectrometry [17] (ICP-AES) and mass spectrometry (ICP-MS). Each one of these has one's own advantages and limitations with regard to accuracy, precision, sensitivity and specificity. The advent of ICP-AES and ICP-MS all with multi-element capabilities has slowed the AAS/AES market. However, AAS/AES technology is deeply entrenched in the field of analytical chemistry.

Several workers from different countries have reported the analysis of medicinal herbs of their respective countries. Lin et al. [18] detected 32 elements in 16 medicinal herbs by ICP-AES. Zhang et al. [19] employing ICP- 
AES for detecting major, minor and trace elements in 26 Chinese traditional drugs and compare their results with those obtained by AAS and NAA. Fan et al. [20] detected $\mathrm{Cu}, \mathrm{Fe}, \mathrm{Mn}, \mathrm{Zn}, \mathrm{Cr}, \mathrm{Mo}, \mathrm{Se}, \mathrm{B}, \mathrm{K}, \mathrm{Ca}, \mathrm{Mg}, \mathrm{F}^{-}, \mathrm{Cl}^{-}$ in 13 diverse drugs by mean of AAS and HPLC methods. Shuping and Chen [21] detected $\mathrm{Zn}, \mathrm{Fe}, \mathrm{Cu}, \mathrm{Cr}, \mathrm{Co}, \mathrm{Ni}$, $\mathrm{Mo}, \mathrm{Sr}, \mathrm{Cd}$ and $\mathrm{Br}$ in seven medicinal herbs by employing ICP-AES. Yuan [22] detected 16 elements in 6 Traditional Chinese Medicines by AAS. Chen et al. [23] and $\mathrm{Xu}$ et al. [24] determined several elements in TCMs by AAS. Wang et al. [25] used ICP-MS for determined metal contents in several TCMs. Zhang [26] employed FAAS for determining $\mathrm{Zn}, \mathrm{Mn}$ and $\mathrm{Cu}$ in chinese medicinal herbs and drugs used in treatment of kidney diseases. Zhang et al. [27] determined 21 trace elements in 10 TCM samples by employing flame and graphite furnace AAS techniques. Jain et al. [28,29] reported AAS and flame photometric determination of 19 elements in several medicinal plants. Saily et al. [30,31] analyzed about 40 medicinal plants for 18 elements. It has been reported that $\mathrm{Na}, \mathrm{Mg}, \mathrm{Ca}, \mathrm{Cr}, \mathrm{Mn}, \mathrm{Fe}, \mathrm{Co}$ and $\mathrm{Zn}$ contents were common in many medicinal plants used for the treatment of asthama, rheumatism, diarrhoea etc. Further Sondhi et al. [32-34] have determined 20 elements in Ayurvedic bhasmas (medicine) used for the treatment of bronchitis, kidney and bladder disorder, skin diseases and Gonorrhoea by employing AAS, ICP-AES and flame photometer. Arun Kumar et al. [35] analyzed macro and micro nutrients in 5 Indian medicinal herbs by applying FAS and AAS method.

In the present study we have attempted to analyse specific parts of 3 herbal medicines which are often recommended as to cure general weakness. Nomenclature and uses of medicinal herbs analyzed in this study are listed in Table 1.

\section{EXPERIMENTAL}

\subsection{Sampling}

All the medicinal herbs were procured from the local market through dealers of herbal medicines. These were cleaned and then swiped to remove all the dust. These were further washed with distilled water and then afterwards swiped with tissue paper. The plant material was first dried in an oven and then dried under IR Lamp at temperature $<70^{\circ} \mathrm{C}$. The dried plant material was grounded to a fine powder (100 mesh) in an agate mortar. The powdered samples were stored in pre-cleaned polyethylene vials and handled with extreme care in a glove box to avoid contamination. Synthetic multielemental standards were prepared by spiking $2-5 \mu \mathrm{g}$ amounts of $\mathrm{Cr}, \mathrm{Mn}, \mathrm{Fe}$, $\mathrm{Co}, \mathrm{Ni}, \mathrm{Cu}, \mathrm{Zn}, \mathrm{Cd}, \mathrm{Ca}, \mathrm{Mg}, \mathrm{Na}$ and $\mathrm{K}$ in aqueous solution of their respective $\mathrm{AR} /$ high purity grade salts.
Table 1. Some characteristics of herbal medicines analyzed in this study.

\begin{tabular}{|c|c|c|}
\hline NAME & $\begin{array}{c}\text { BOTANICAL } \\
\text { NAME }\end{array}$ & USES \\
\hline $\begin{array}{l}\text { BEEZBAND } \\
\text { (Seeds) }\end{array}$ & Sida cordifolia & $\begin{array}{l}\text { Eye diseases, Paralysis, Cardiac } \\
\text { Disorder chest Injury, } \\
\text { Leucorrhoea, Fever, Weakeness, } \\
\text { T.B. Inflammation } \\
\text { Blood disorder }\end{array}$ \\
\hline $\begin{array}{l}\text { GOKSHUR } \\
\text { (Fruit) }\end{array}$ & $\begin{array}{l}\text { Tribulus } \\
\text { terrestris }\end{array}$ & $\begin{array}{l}\text { Dysurea, Nephritis, Diretic, } \\
\text { Stomachic, Health promoter, } \\
\text { Urinary Lithntriptic, } \\
\text { Calculus, Impotency, } \\
\text { Seminal debility Aphrodisiac } \\
\text { hair Growth Promotive }\end{array}$ \\
\hline $\begin{array}{l}\text { TALMAKHANA } \\
\text { (seed) }\end{array}$ & $\begin{array}{c}\text { Asteracantha } \\
\text { longifolia }\end{array}$ & $\begin{array}{l}\text { Oesteoartheritis, rheumatide } \\
\text { Artheritis, Hepatesis, Gastric } \\
\text { Disorder, Gout, Annemia, } \\
\text { Sterility, Nightfall, } \\
\text { Urinary stone, General } \\
\text { Weakness, Dysentery }\end{array}$ \\
\hline
\end{tabular}

\subsection{AAS Measurements}

For the analysis of $\mathrm{Mg}, \mathrm{Ca}, \mathrm{Cr}, \mathrm{Mn}, \mathrm{Fe}, \mathrm{Co}, \mathrm{Ni}, \mathrm{Cu}, \mathrm{Zn}$ and $\mathrm{Cd}$ by AAS method, about $2 \mathrm{~g}$ of each sample were accurately weighed and digested in 5:1 mixture of nitric acid and perchloric acid. After digestion, two to three drops of $\mathrm{HCl}$ was added and the solution was made up to $25 \mathrm{~mL}$., $\mathrm{Ca}, \mathrm{Cd}, \mathrm{Co}, \mathrm{Cr}, \mathrm{Cu}, \mathrm{Fe}, \mathrm{Mg}, \mathrm{Mn}, \mathrm{Ni}$ and $\mathrm{Zn}$ were determined by Atomic Absorption Spectrophotometer (GBC Avanta, Australia) using a mixture acetylene-air flame. The wavelength and senstivities for these elements were $422.7 \mathrm{~nm}$ and $4 \mu \mathrm{g} / \mathrm{g} ; 228.8 \mathrm{~nm}$ and $1.5 \mu \mathrm{g} / \mathrm{g}$, $240.7 \mathrm{~nm}$ and $7 \mu \mathrm{g} / \mathrm{g} ; 357.9 \mathrm{~nm}$ and $4 \mu \mathrm{g} / \mathrm{g} ; 324.8 \mathrm{~nm}$ and $4 \mu \mathrm{g} / \mathrm{g} ; 248.3 \mathrm{~nm}$ and $5 \mu \mathrm{g} / \mathrm{g} ; 285.2 \mathrm{~nm}$ and $0.3 \mu \mathrm{g} / \mathrm{g}$; $279.5 \mathrm{~nm}$ and $2.5 \mu \mathrm{g} / \mathrm{g} ; 232.0 \mathrm{~nm}$ and $7.0 \mu \mathrm{g} / \mathrm{g}$ and 213.9 $\mathrm{nm}$ and $1.0 \mu \mathrm{g} / \mathrm{g}$ respectively. The instrument was precalibrated using high purity grade salts of respective elements.

\section{RESULTS AND DISCUSSION}

Elemental concentrations in 3 medicinal herbs (Gokshur, Beezband and Talmakhana) are used to cure sexual weakness were measured by relative method of AAS by using RMs and multielemental standards as comparators. Only if the values for elemental concentrations in RMs matched well within $\pm 10 \%$ of the certified values, the values for sample were considered. These are listed in Table 2. Also included in the same tables are our data for participation in the analysis of dipleted Pine Needle (SRM 1575a). In each case triplicate analyses were made using $100 \mathrm{mg}$ each. It was observed that standard deviations for most elements were small suggesting a good precision. On the basis of good agreement, it is presumed that out values are listed in Table 2 should be accurate and precise within $\pm 10 \%$. In order to compare the mean 
Table 2. Elemental concentrations in medicinal plants.

\begin{tabular}{ccccc}
\hline Elements & SRM Pine Needle (1575a) & Gokshur & Beezband (Bala) & Talmakhana \\
\hline $\mathrm{Na}(\mathrm{mg} / \mathrm{g})$ & $0.40(-)$ & 0.125 & 0.120 & 0.125 \\
$\mathrm{~K}(\mathrm{mg} / \mathrm{g})$ & 5.0 & $1.00(3.70 \pm 0.20)$ & 0.50 & 0.05 \\
$\mathrm{Ca}(\mathrm{mg} / \mathrm{g})$ & 4.12 & $44.2(4.10 \pm 0.20)$ & 9.6 & 13.6 \\
$\mathrm{Mg}(\mathrm{mg} / \mathrm{g})$ & $3.24(-)$ & 8.43 & 4.4 & 8.7 \\
$\mathrm{Fe}(\mu \mathrm{g} / \mathrm{g})$ & 210 & $4500(200 \pm 10)$ & 600 & 1550 \\
$\mathrm{Cr}(\mu \mathrm{g} / \mathrm{g})$ & 3.2 & $2.5(3.0 \pm 0.3)$ & 1.0 & 3.0 \\
$\mathrm{Co}(\mu \mathrm{g} / \mathrm{g})$ & 0.10 & $3.7(0.10)$ & 3.9 & 0.8 \\
$\mathrm{Zn}(\mu \mathrm{g} / \mathrm{g})$ & - & 1.1 & 9.0 & 7.6 \\
$\mathrm{Ni}(\mu \mathrm{g} / \mathrm{g})$ & $3.50(3.5)$ & 6.7 & 40 & 51 \\
$\mathrm{Cd}(\mu \mathrm{g} / \mathrm{g})$ & 0.50 & $<0.1$ & 1.0 & 0.1 \\
\hline
\end{tabular}

Note: in parenthesis are given certified values from literature.

elemental concentrations of 3 medicinal herbs for $\mathrm{Na}, \mathrm{K}$, $\mathrm{Ca}, \mathrm{Mg}, \mathrm{Fe}, \mathrm{Cu}, \mathrm{Mn}, \mathrm{Cr}, \mathrm{Zn}$ and $\mathrm{Co}$ are plotted in Figure 1. The herbs of Jaunpur origin are found to contain some rare elements in amounts larger than other places.

A perusal of data in Table 2 show that no single herb is enriched in all the elements. The electrolytic elements $\mathrm{Na}$ and $\mathrm{K}$ responsible for maintaining normal fluid balance inside and outside cells are generally found at minor and major concentration levels respectively. All the samples have shown much higher concentration of $\mathrm{K}$ by up to an order of magnitude compared to that of $\mathrm{Na}$.

The analysis of selected herbs leads to the following results:

1) Beezband: The seed of this herb contains $\mathrm{Na}(0.120)$,

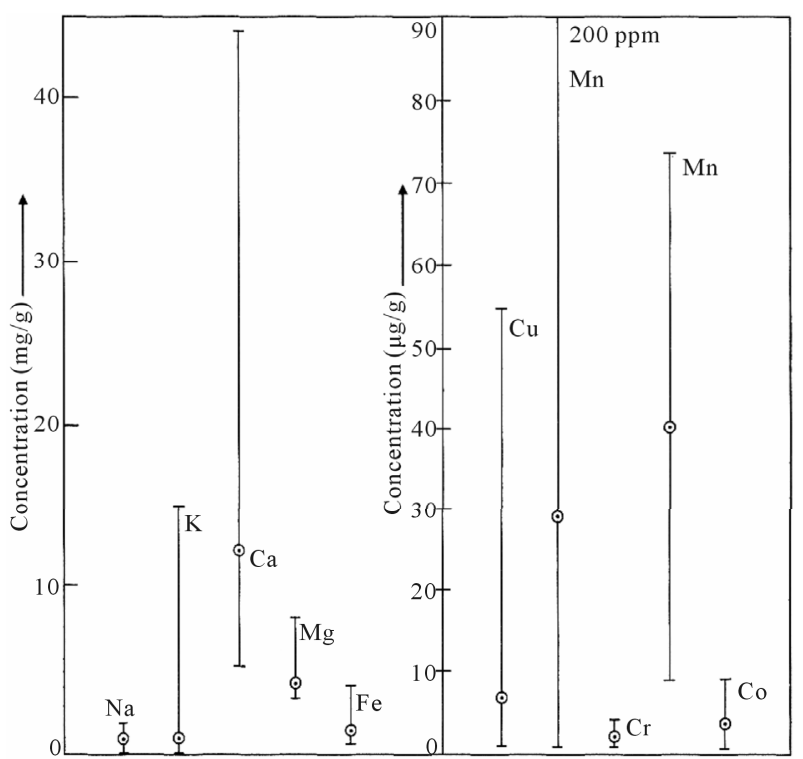

Figure 1. Comparison of elemental contents (rang and median values) in medicinal herbs.
$\mathrm{K}(0.50), \mathrm{Ca}$ (9.6), $\mathrm{Mg}$ (4.4) in $\mathrm{mg} / \mathrm{g}$ and $\mathrm{Fe}(600), \mathrm{Cr}$ (1.0), Mn (28), Co (3.9), Cu (2.3), Zn (9.0), Ni (40) and $\mathrm{Cd}(1.0) \mu \mathrm{g} / \mathrm{g}$. Other plant organs were not analysed as they have negligible medicinal significance.

2) Gokshur: The fruit of this herb contains $\mathrm{Na}(0.125)$, $\mathrm{K}$ (1.00), $\mathrm{Ca}$ (44.2), $\mathrm{Mg}$ (8.43) in $\mathrm{mg} / \mathrm{g}$ and $\mathrm{Fe}$ (4500), $\mathrm{Cr}$ (2.5), Mn (10), Co (3.7), Cu (3.7), Zn (1.1), Ni (67) and $\mathrm{Cd}(<1.0) \mu \mathrm{g} / \mathrm{g}$. Other plant organs were not analysed as they have negligible medicinal significance.

3) Talmakhana: The seed of this herb contains $\mathrm{Na}$ (0.125), $\mathrm{K}(0.05), \mathrm{Ca}(13.6), \mathrm{Mg}(8.7)$ in $\mathrm{mg} / \mathrm{g}$ and $\mathrm{Fe}$ (1550), Cr (3.0), Mn (31), Co (0.8), Cu (4.5), Zn (7.6), $\mathrm{Ni}(51)$ and $\mathrm{Cd}(0.1) \mu \mathrm{g} / \mathrm{g}$. Other plant organs were not analysed as they have negligible medicinal significance.

Beezband has highest amount of $\mathrm{Cu}(9 \mu \mathrm{g} / \mathrm{g})$ where as Talmakhana has highest amount of $\mathrm{Ca}(13.6 \mathrm{mg} / \mathrm{g}), \mathrm{Mg}$ $(8.7 \mathrm{mg} / \mathrm{g}), \mathrm{Fe}(1.55 \mathrm{mg} / \mathrm{g}), \mathrm{Cr}(3.0 \mu \mathrm{g} / \mathrm{g})$ and $\mathrm{Ni}(9.5$ $\mu \mathrm{g} / \mathrm{g})$. Gokshur has highest amount of $\mathrm{Fe}$ and $\mathrm{Ni}$ and lowest amount of $\mathrm{Na}$. All these are prescribed to patient suffering from general weakness. Interestingly Beezband is used in cardic disorder, seminal debility and urinary stone where as Talmakhana is used in anaemia, rheumatide, sterility and urinary stone and Gokshur is used as health promoter, seminal debility, hair growth promoter. The accountability of different components for medicinal potency may be a search light for physican and dieticians.

\section{CONCLUSION}

Three herbal medicines namely Beezband (seed), Gokshur (fruit) and Talmakhana (seed) commonly used to cure general weakness have been analyzed for 10 essential nutrients ( $\mathrm{Na}, \mathrm{K}, \mathrm{Ca}, \mathrm{Mg}, \mathrm{Fe}, \mathrm{Cr}, \mathrm{Mn}, \mathrm{Co}, \mathrm{Cu}$ and $\mathrm{Zn}$ ) and 2 toxic elements ( $\mathrm{Ni}$ and $\mathrm{Cd}$ ) by flame photometry 
and AAS. The elemental data should is reliable within $\pm 10 \%$. On the basis of elemental data in 3 medicinal herbs commonly used to cure general weakness following conclusion may be drawn:

1) Different parts of medicinal plants are enriched in some or other nutrient elements especially for $\mathrm{Ca}, \mathrm{Fe}$, $\mathrm{Mn}, \mathrm{Cu}$ and $\mathrm{Zn}$.

2) No particular plant is enriched in all the elements.

3) In general iron is enriched in all the medicinal herbs as there are used as brain tonics.

4) Elemental contents of environmental contaminants are minimal so as not to cause any harm to our body system.

\section{ACKNOWLEDGEMENTS}

The first author (Arun Kumar) grateful to Prof. G. Bhattacharjee, Head, Department of Chemistry, University of Roorkee, Roorkee (at present IIT Roorkee) for providing all the facilities during the course of this work. I am also thankful to all the faculty members of the Department of Chemistry for their timely suggestions and moral support. I would like to express my grateful thanks Prof. Indu Mehrotra, Environmental Engineering Section, Civil Engineering Department, University of Roorkee, Roorkee for permission to use their flame photometer and full co-operation during experimental work.

\section{REFERENCES}

[1] Sivarajan, V.V. and Balachandran, I. (1994) Ayurvedic drugs and their plant sources. Oxford and IBH Publishing Co. Pvt. Ltd., New Delhi, 570.

[2] Zhou, J., Xie, G. and Yan, X. (Eds.) (2003) Traditional Chinese Medicines. Ashgate Publishing, Oxon.

[3] Steiner, R.P. (1986) Folk medicine: The art and the science. American Chemical Society, Washington DC, 223.

[4] Kanias, G.D., Kilikoglou, V., Tsitsa, E. and Loukis, A. (1993) Determination and statistical analysis of trace element and active constituent concentrations in the medicinal plant Eucalyptus camaldulensis Dehnh (E. rostratus Schlecht). Journal of Radioanalytical and Nuclear Chemistry, 169, 483-491. doi:10.1007/BF02043005

[5] El-Mekkawy, S., Meselhy, M.R., Kusumoto, I.T., Kadota, S., Hattori, M. and Namba, T. (1995) Inhibitory effects of egyptian folk medicines oh human immunodeficiency virus (HIV) reverse transcriptase. Chemical \& Pharmaceutical Bulletin, 43, 641-648. doi:10.1248/cpb.43.641

[6] Parchure, S.N. (1983) Charak samhita, Vol. 1-3. Sagar Publications, Pune.

[7] Sharma, P.V. (1993) Dravya guna vigyan. Chaukhamba Bharati Academy, Varanasi.

[8] Rastogi, R.P. and Mehrotra, B.N. (1998-2002) Compendium of Indian medicinal plants, Vol. 1-6. Central Drug Research Institute/National Institute of Science Communication, Lucknow/New Delhi.

[9] Bakhru, H.K. (1998) Herbs that heal natural remedies for good health, Orient paper backs. Division of Vision Book
Pvt. Ltd., New Delhi.

[10] Prasad, A.S. (1993) Essential and toxic elements in human health and disease; an update. Wiley-Liss, New York.

[11] O'Dell, B.L. and Sunde, R.A. (Eds.) (1997) Handbook of nutritionally essential mineral elements. Marcel Dekker Inc., New York.

[12] Iyengar, G.V. (1989) Elemental analysis of biological systems-biomedical, environmental in: Compositional and methodological aspects of trace elements. CRC Press, Boca Raton.

[13] Seiler, H.G., Sigel, A. and Sigel, H. (Eds.) (1994) Handbook on metals in clinical and analytical chemistry. Marcell Dekker Inc., New York.

[14] Herber, R.F.M. and Stoeppler, M. (Eds.) (1994) Trace element analysis in biological specimens. Elsevier, New York.

[15] Joseph D., Lal, M., Bajpai, H.N. and Mathur, P.K. (1999) Levels of trace elements of a few Indian spices by energy dispersive X-ray fluorescence. Journal of Food Science and Technology, 36, 264-265.

[16] Scancar, J., Milacic, R., Falnoga, I., Cemazar, M. and Bukovec, P. (2000) Use of nitric acid in sample pretreatment for determination of trace elements in various biological samples by ETAAS. Journal of Pharmaceutical and Biomedical Analysis, 22, 993-1002. doi:10.1016/S0731-7085(00)00305-8

[17] Chan, Y.Y. and Lo, S.C.L. (2003) Analysis of Ling Zhi (Ganoderma lucidum) using dynamic reaction cell ICPMS and ICP-AES. Journal of Analytical Atomic Spectrometry, 18, 146-150. doi:10.1039/b212283a

[18] Lin, S., Zhao L. and Yan, Y. (1991) Zhongguo Zhongyao Zazhi, 16, 222.

[19] Zhang, X., Duan Y. and Wang, X. (1991) Fenxi Huazue, 19, 835 .

[20] Fan, X., Chen, Y., He, L., Hu, Q., Shi, Y., Tian, C., Wang, C., Wang, S. and Yang, Z. (1993) Fenxi Shiyanshi, 12, 32.

[21] Shuping, H. and Chen, L. (1994) Senxi Daxue Xuebao, 177, 56.

[22] Yuan, A. (1998) Guangdong Weiliang Yuansukexue, 5.

[23] Chen, X., Cao, S., Zhou, P., Zheng, Y. and Huang, J. (1998) Zhongcaoyao, 29, 808.

[24] Xu, X., Yen, G., Sun, G., Sun, X., Tian, L. and Wang, S. (1998). Shizheu Daxue Xuebao Ziran Kexueban, 2, 43.

[25] Wang, X., Zhuang, Z., Sun, D., Hong, J., Wu, X., Lee, F., Yang, M. and Leung, H.W. (1999) At. Spectro, 20, 86.

[26] Zhang, T. (1999) Zhongguo Yiyuan Yaoxue Zazhi, 19, 345.

[27] Zhang, Q.F., Peng, S.S., Ni, N., Hu, X.Y. and Yang, W.Y. (1999) Guangpuxue Yu Gungpu Fenxi, 19, 203.

[28] Jain, N., Shahoo, R.K. and Sondhi, S.M. (1992) Indian Drugs, 29, 187.

[29] Jain, N., Magan, A. and Sondhi, S.M. (1993) Indian Drugs, 30, 190.

[30] Saily, A., Sahu, R., Mohan, D., Gupta, B. and Sondhi, S.M. (1994) Indian Journal of Pharmaceutical Science, 56, 186.

[31] Saily, A., Sahu, R., Gupta, B. and Sondhi, S.M. (1994) Hamdard, 37, 18. 
[32] Sondhi, S.M. and Janani, G.K. (1995) Indian Drugs, 32, 125.

[33] Sondhi, S.M. and Agarwal, N. (1995) Hamdard Medicus, 38, 24.

[34] Sondhi, S.M., Sharma, V.K. and Verma, R.P. (1995) In- dian Drugs, 33, 67.

[35] Kumar, A., Singh, R.P. and Singh, N.P. (2011) Analysis of macro and micro nutrients in some Indian medicinal herbs grown in Jaunpur (u.p) soil. Natural Science, 3, 551-555. doi:10.4236/ns.2011.37077 